\title{
Mind the Gap! ECN+ Directive Proposal on its Way to Eliminate Deficiencies of Regulation 1/2003: Polish Perspective
}

\author{
Agata Jurkowska-Gomułka*
}

\begin{abstract}
This article aims at answering the question whether the Commission's proposal intended to empower Member States' competition authorities to be more effective enforcers (ECN+ Directive) actually brings effective solutions to all weaknesses of Regulation 1/2003, which influenced an inefficient application of Articles 101 and 102 TFEU in some Member States (among them Poland, which will be taken as a point of reference).

The first part of the article constitutes a review upon the application of Regulation 1/2003 in Poland. Interestingly, the beginning of its enforcement coincides with the total period of application of EU law in Poland, since the country joined the EU on the same day the Regulation entered into force. The problem with Regulation 1/2003 is that it does not seem to enhance the enforcement of the Community's competition rules by national enforcers, including NCAs and courts. The reason for this failure lies inter alia in the deficiencies of the principles adopted in the Regulation itself, including a lack of procedural unification (or at least some harmonisation) in cases where European substantive law is to be applied.

In the second part of the article, the content of the Commission's proposal on ECN+ Directive is analysed in order to find whether new regulations are able to solve problems identified in the Polish application of the Treaty's provisions. The article concludes with an overall assessment of the proposed Directive and a list of conditions for effective implementation of the Directive.
\end{abstract}

\footnotetext{
* Agata Jurkowka-Gomulka is a Professor of Law at the University of Information Technology and Management, Faculty of Administration and Social Sciences, Chair of Administrative Science; Of-counsel, Modzelewska\&Paśnik, Warsaw, 35-225 Rzeszów, Poland. ajurkowska@wsiz.rzeszow.pl. The author would like to thank Małgorzata Modzelewska de Raad, attorney, for the valuable remarks upon barriers in applying EU competition law in Member States.
} 
KEYWORDS: ECN+; competition authority; empowerment; national enforcer; Regulation 1/2003.

\section{Introductory remarks}

Regulation 1/2003 was based on a quite brave concept: its objective was to assure the application of Articles 101 and 102 TFEU in a single (uniform) manner across the EU; yet, no a concrete harmonisation of procedural rules was foreseen therein. ${ }^{1}$ Some instruments for harmonising some procedural issues can, indeed, be found in Regulation 1/2003, such as a catalogue of decisions that can be adopted by national competition authorities in cases based on Treaty provisions, but jurisprudence shows that even a provision laid down in this instrument (Article 5 of Regulation 1/2003) has caused serious problems in its interpretation. ${ }^{2}$ The Commission's report assessing the implementation of Regulation 1/2003 (hereafter, Anniversary Communication) ${ }^{3}$ created the impression that, by enforcing Regulation 1/2003, European institutions (the Council as a legal maker, but predominantly the Commission as a law initiator) had hoped for a sort of spontaneous harmonisation of the European Competition Network, which - even if not founded directly by Regulation 1/2003 was mentioned in its motives and eventually set up on the basis of the Commission's communication. ${ }^{4}$ It is remarkable that, in the Anniversary Communication, both ECN's existence and its initiatives were highlighted as the key (the only?) achievement of Regulation 1/2003. ${ }^{5}$ In 2014, the Commission honestly presented itself as disillusioned - a uniform

\footnotetext{
${ }^{1}$ A problem of an influence of differences between procedural rules upon results of applying EU and national rules was highlighted by e.g. Kati Cseres, "The impact of Regulation 1/2003 in the New Member States," The Competition Law Review 6, no. 2 (2010): 161, 182. The author states: "Diverging procedural rules demonstrate that national procedural autonomy is still a powerful influencing device on the outcome of enforcement of EU rules" (182).

2 Judgement of the Court of Justice of 3 May 2011, Tele 2 v. President of Office of Competition and Consumer Protection, C-375/09, EU:C:2011:270.

${ }^{3}$ Communication from the Commission - Ten Years of Antitrust Enforcement under Regulation 1/2003: Achievements and Future Perspectives (COM (2014) 453, 9.7.2014).

${ }^{4}$ Commission Notice on cooperation within the Network of Competition Authorities, [2004] OJ C $101 / 43$.

${ }^{5}$ Doubts on the compliance of ECN's activities with the rule of law are correctly pointed by Giorgio Monti, "Independence, interdependence and legitimacy: The EU Commission, National Competition Authorities, and the European Competition Network", EUI Working Paper LAW 1 (2014): 16-18.
} 
application of EU competition law without a previous harmonisation of procedural rules was, indeed, impossible.

In 2017, after thirteen years of application of Regulation $1 / 2003^{6}$, most antitrust lawyers, including some from the Commission, were deeply convinced that a time for a change had come. This expectation was preliminarily met by a Proposal for a Directive of the European Parliament and of the Council to empower Member States' competition authorities to be more effective enforcers and to ensure the proper functioning of the internal market, ${ }^{7}$ commonly known as the ECN+ Directive Proposal. The very basic question arising in the context of the draft Directive which should be profoundly reflected upon is: will a planned ECN+ Directive be able to eliminate all weaknesses of a current system of enforcement of EU competition rules in Member States? One of the goals of this article is to answer this question by taking into consideration the case of Poland a large country with a considerable economy that turned out to be a very inefficient enforcer of EU competition rules.

In order to achieve this goal, the article is divided into five sections. The first is an introduction. The second one summarises and comments on the Polish antitrust practice regarding Articles 101 and 102 TFEU. ${ }^{8}$ The third section identifies Poland's key problems regarding the application of EU competition rules - both the Treaty rules and Regulation 1/2003 - at a national level. This list differs from the list of gaps contained in the ECN+ Directive proposal, ${ }^{9}$ but it sums up the Polish experience. Simultaneously, the second section brings Regulation 1/2003's weaknesses into view from a Polish perspective. In the fourth part of the article, the content of the ECN+ Directive Proposal is analysed from a standpoint of the problems identified in the previous section. The article finishes with section five,

\footnotetext{
${ }^{6}$ Council Regulation (EC) No. 1/2003 of 16 December 2002 on the implementation of the rules on competition laid down in Articles 81 and 82 of the Treaty, OJ 2003 L 1, 1-25. The genesis of this Regulation is interestingly presented by Wouter Wils, "Ten years of Regulation 1/2003 - A retrospective", Journal of Competition Law and Practice 4, no. 4 (2013) (version available from SSRN, hereafter: SSRN's version).

${ }^{7}$ Proposal for a Directive of the European Parliament and of the Council to empower the competition authorities of the Member States to be more effective enforcers and to ensure the proper functioning of the internal market, Brussels, 22.3.2017, $\operatorname{COM}(2017) 142$ final, $\{\operatorname{SWD}(2017) 114\}$, $\{$ SWD(2017) 115\}, \{SWD(2017) 116\}; hereafter: the ECN+ Directive Proposal or the draft Directive. ${ }^{8}$ Consolidated version of the Treaty on the Functioning of the European Union, [2012] OJ C $326 / 47$.

${ }^{9}$ See ECN+ Proposal, 2-3 (under the heading: Reasons for and objectives of the proposal).
} 
which provides an overall assessment of the proposed Directive, accompanied by a list of conditions for effective implementation of the Directive in Poland.

\section{Poland: the (poor) story of an application of Regulation 1/2003}

For Poland, 1 May 2004 was not only the day Regulation 1/2003 entered into force, but also (as for other nine of the (current) 28 Member States) a memorable day regarding the country's accession to the EU with all its policies (competition policy included). The so-called "new" Member States Regulation 1/2003 was not only considered as revolutionary, but also as a starting point for the enforcement of EU competition rules. Therefore, the assessment of the application of Regulation 1/2003 in the new Member States regards a "pure" application of Regulation 1/2003, not influenced by a comparison between "new" and "old" regimes (Regulation 17/62). But this is probably the beginning and the end of the differences between EU "newcomers" and EU incumbent Member States in terms of the application of Articles 101 and 102 TFEU on the basis of Regulation 1/2003. ${ }^{10}$ Therefore, all the remarks and conclusions presented in this article can be successfully applied to many (if not all) national antitrust regimes in the EU.

Until the end of 2016, ${ }^{11}$ the President of the Competition and Consumer Protection Office (NCA in Poland, hereafter, UOKiK) only completed 23 antitrust proceedings based on Articles 101 and 102 TFEU. The total number of proceedings based on the Treaty provisions is not clear because until 2012 UOKiK did not contain such data in its annual reports. Detailed information is presented below in Table 1 .

\footnotetext{
${ }^{10}$ However, see an interesting analysis of the application of EU competition rules in small new Member States: Jurgita Malinauskaite, "Public EU competition law enforcement in small 'newer' Member States: Addressing the challenges", The Competition Law Review 12, no. 1 (2016): 19-52. ${ }^{11}$ At the submission date of this paper, the full data on UOKiK's activity were not available yet.
} 
Table 1. Number of antitrust proceedings based on Article 101 and/or Article 102 TFEU initiated, continued and completed by the Polish competition authority between 2004 and 2016 .

\begin{tabular}{|c|c|c|c|}
\hline Year & $\begin{array}{c}\text { Number of proceedings } \\
\text { initiated }\end{array}$ & $\begin{array}{l}\text { Number of proceedings } \\
\text { continued }\end{array}$ & $\begin{array}{c}\text { Number of proceedings } \\
\text { completed }\end{array}$ \\
\hline \multirow{2}{*}{2016} & $0(101)$ & $1(101)$ & $0(101)$ \\
\hline & $0(102)$ & $0(102)$ & $0(102)$ \\
\hline \multirow{2}{*}{2015} & $0(101)$ & $2(101)$ & $1(101)$ \\
\hline & $0(102)$ & $1(102)$ & $0(102)$ \\
\hline \multirow{2}{*}{2014} & $0(101)$ & $2(101)$ & $0(101)$ \\
\hline & $0(102)$ & $1(102)$ & $0(102)$ \\
\hline \multirow{2}{*}{2013} & $1(101)$ & $1(101)$ & $0(101)$ \\
\hline & $2(102)$ & $0(102)$ & $1(102)$ \\
\hline \multirow{2}{*}{2012} & $1(101)$ & $0(101)$ & $0(101)$ \\
\hline & $0(102)$ & $1(102)$ & $1(102)$ \\
\hline \multirow{2}{*}{2011} & \multirow{2}{*}{ No data available } & \multirow{2}{*}{ No data available } & $1(101)$ \\
\hline & & & $0(102)$ \\
\hline \multirow{2}{*}{2010} & \multirow{2}{*}{ No data available } & $0(101)$ & $0(101)$ \\
\hline & & $2(102)$ & $2(102)$ \\
\hline \multirow{2}{*}{2009} & \multirow{2}{*}{ No data available } & $4(101)$ & $4(101)$ \\
\hline & & $3(102)$ & $2(102)$ \\
\hline \multirow{2}{*}{2008} & \multirow{2}{*}{ No data available } & $5(101)$ & $2(101)$ \\
\hline & & $6(102)$ & $3(102)$ \\
\hline \multirow{2}{*}{2007} & \multirow{2}{*}{ No data available } & $1(101)$ & $1(101)$ \\
\hline & & $7(102)$ & $2(102)$ \\
\hline \multirow{2}{*}{2006} & \multirow{2}{*}{ No data available } & \multirow{2}{*}{$11(101 \& 102)$} & $1(101)$ \\
\hline & & & $3(102)$ \\
\hline \multirow{2}{*}{2005} & \multirow{2}{*}{ No data available } & \multirow{2}{*}{$8(101 \& 102)$} & $0(101)$ \\
\hline & & & $0(102)$ \\
\hline \multirow{2}{*}{2004} & $1(101)$ & $1(101)$ & $0(101)$ \\
\hline & $1(102)$ & $1(102)$ & $0(102)$ \\
\hline
\end{tabular}

Source: Author's analysis of UOKiK's annual reports, available at: www.uokik.gov.pl (15 January 2018).

NDAR The number of envisaged decisions (Article 11(4) of Regulation 1/2003) in Poland between 2004 and 2017 is really modest. ECN's statistics show a much larger number of such decisions in many "new" Member States, which can be quite surprising, considering the fact that Poland constitutes the largest market out of all new EU Member States and the sixth market in the whole EU. A competition authority in Hungary issued 41 decisions, 
in Lithuania - 16, in Romania - 36, and in Slovakia - 23, while Poland only issued $13 .{ }^{12}$ W.P.J. Wils noticed that Poland and the United Kingdom are "the notable exceptions" to the rule that the largest Member States adopt the largest number of decisions based on Article 101 and/or Article 102 TFEU. ${ }^{13}$

Not only the total number of decisions, but also the scope of UOKiK's activity regarding the application of EU competition rules is disappointing. It would be expectable that the number of Polish national antitrust proceedings based on Article 101 and/or Article 102 TFEU would increase (or at least not decrease) given the fact that Regulation 1/2003 has been in force for many years, the co-operation within ECN has grown and the competition authority itself has gained some experience in applying the Treaty's competition rules. But what is striking while analysing UOKiK's activity is the significant decrease in initiating (and consequently conducting and completing) antitrust proceedings with EU dimension (comparing the periods ranging from 2005-2009 and 2010-2016).

It is doubtful whether the real reason for UOKiK's inactivity regarding the application of Articles 101 and 102 TFEU is the lack of infringements with EU dimensions, because to some point this decrease reflects the performance of a national competition policy. The number of antitrust proceedings initiated and completed by the UOKiK has decreased in recent years - this situation is a consequence of a set of factors of different natures. First of all, since April 2007 antitrust proceedings before the Polish competition authority regarding EU competition rules can only be started ex officio. Secondly, the President of UOKiK is not only a competition authority, but simultaneously an authority in a vast area of consumer cases, which surely has an impact on the quality of the competition policy.

Moreover, a record of antitrust decisions issued by the President of UOKiK in recent years shows that a majority of them concerned abuses of dominant position on local markets of public utility services and hardly any infringements of this kind are subject to Article 102 TFEU. For a long time, decisions concerning infringements of a prohibition of anticompetitive agreements (Article 6 of Polish Competition Act ${ }^{14}$ ) in vertical agreements rather dominated in Poland. Then, a great number of antitrust decisions concerned bid rigging on local market. Again, these types of restrictions

\footnotetext{
${ }^{12}$ All data available at: http://ec.europa.eu/competition/ecn/statistics.html (15 January 2018).

${ }^{13}$ Wouter Wils, "Ten Years", 9.

${ }^{14}$ Act of 16 February 2007 on Competition and Consumer Protection, consolidated text: Polish Journals of Law 2017, item 229, 1089, 1132.
} 
of competition can rarely be caught by Article 101 TFEU, mainly because of the absence of impact on intra-EU trade patterns. Surely, also some deficiencies of Regulation 1/2003 that will be discussed later in this article can be (at least partly) blamed for a poor performance of the Polish competition authority in the application of EU antitrust provisions.

\section{Key problems of applying Articles 101 and 102 TFEU at national level}

\section{1. (Modest) analysis of an "impact on trade among EU Member States"}

What seems to be specific for the Polish record of decisions based on Articles 101 and 102 TFEU is that, in a vast majority of cases, violations of Treaty provisions confirmed by a national competition authority regard these categories of restrictions of competition (categories defined mainly by a relevant market and its characteristics, type of industry (business), and type and size of a company, which in the past used to be declared as violating Articles 101 or 102 TFEU by the Commission). Restricting competition on a domestic gas market - as in the PGNiG cases - was considered to have an impact on intra-EU trade, as in the Commission's decisions in the Gaz de France/Suez $z^{15}$ and Total/Gaz de France ${ }^{16}$ cases. It is also possible to find analogies in a record of the Commission's decisions for other cases assessed by the Polish competition authority: ZAIKS (e.g. the Commission's decisions in the GEMA ${ }^{17}$ and SACEM ${ }^{18}$ cases), Wrigley (Mars/Wrigley case ${ }^{19}$ ), PPL (e.g. Alpha Fight Services/Aéroports de Paris case $^{20}$ ), or the interchange fee case (Visa case $\left.{ }^{21}\right)$. The Polish competition authority does not seem to be very brave or adventurous in identifying brand new markets subject to an impact on intra-EU trade.

Any qualitative analysis of the impact on trade as a prerequisite for applying Article 101 and 102 TFEU in "Polish" cases is very general and is mainly limited to the statement that an impact on trade is "potential". There are no analyses on how a particular practice can pertain internal market objectives.

\footnotetext{
${ }^{15}$ Decision of the European Commission, 14 November 2006, COMP/M.4180 Gaz de France/Suez.

${ }^{16}$ Decision of the European Commission, 8 October 2004, COMP/M.3410 Total/Gaz de France.

${ }^{17}$ Decision of the European Commission, 2 June 1971, IV/26.760 GEMA, OJ 1973 L 134.

${ }^{18}$ Decision of the European Commission, 12 August 2002, COMP/C2/37.219 Banghalter/Homem Christo (Daft Punk) v. SACEM.

${ }^{19}$ Decision of the European Commission, 28 July 2008, COMP/M.5188, Mars/Wrigley.

${ }^{20}$ Decision of the European Commission 98/513/EC, 11 June 1998 r., Alpha Fight Services/ Aéroports de Paris, OJ L 230/10.

${ }^{21}$ Decision of the European Commission, 24 July 2002, COMP/29.373, Visa.
} 


\section{2. (Lack of) coherent interpretation of EU and national substantive competition rules}

\subsection{1. (Lack of) full identity of national substantive competition rules}

According to Article 3(1) of Regulation 1/2003, Member States "shall also apply" Articles 101 and 102 TFEU together with national competition rules.

It is true that competition rules in Poland and other Central European countries, just as those in Cyprus and Malta (which also accessed the EU on 1 May 2004), have followed the EU regulatory pattern to a great extent. Prerequisites for applying Articles 101 and 102 TFEU, excluding the condition of an impact on trade, are just the same as those contained in respectively - Article 6 and Article 9 of the Polish Competition Act. EU Member States have achieved a certain level of (even if non-mandatory) "harmonization" of national antitrust rules regarding prohibitions of anticompetitive practices, but this "harmonization" did not concern a way in which substantive rules are formulated in a national law, as well as instruments of competition policy at EU and national law can differ (and in reality they often do). This factor has an inevitable influence upon the application of Regulation $1 / 2003$ by national competition authorities.

What seems to be irritating is the fact that national competition authorities seem to ignore the existing disparities between EU and national substantive antitrust rules, which results in the fact that the application of Articles 101 and 102 TFEU is limited to assessing a possible impact on trade between EU Member States - the rest of the conditions for applying the Treaty's provisions are assessed in the same way as the conditions established in a national law.

The need for a separate assessment of prerequisites concerning prohibitions of anticompetitive practices stated in EU and national law was indirectly confirmed by a position of the Commission acting as amicus curiae in a proceeding before the Austrian court in the Schenker case. The Commission claimed that even if an agreement has a de minimis status in accordance with a national law, it cannot be protected from being subject to the application of Article 101 TFEU. $^{22}$

\footnotetext{
${ }^{22}$ See judgment of the Court (Grand Chamber) of 18 June 2013, Bundeswettbewerbsbehörde and Bundeskartellanwalt v. Schenker \& Co. AG and Others, C-681/11, EU:C:2013:404. Commission Staff Working Document SWD (2014) 230 - Ten Years of Antitrust Enforcement under Regulation 1/2003 (SWD(2014) 230/2, 9.7.2014), paragraph 250.
} 
National competition authorities have to bear in mind that when applying Articles 101 and 102 TFEU they have to take into consideration a whole acquis communautaire corresponding to these provisions, including CJEU's jurisprudence. On the other hand, in a process of application of a national law, EU case-law may have a limited meaning. The Polish Supreme Court took a very clear position on this in a few judgments. ${ }^{23}$

As for Poland, the problem seems to be highly visible in the reference to the existence of a dominant position. In EU law there is no legal definition of dominant position, so an assessment of this concept may be more flexible. If a dominant position is determined in a process of application of Article 102 TFEU, a market share as a quantitative criterion of dominance can even be ignored, which is absolutely impossible under Polish law because the criterion of market share constitutes an element of the legal definition of dominance contained in Article 4.10 of the Polish Competition Act. ${ }^{24}$ What is more, according to Article 4.10 of the Competition Act, a market share above $40 \%$ creates a legal presumption that an undertaking holds a dominant position. Even if this presumption is rebuttable, the position of a (possibly dominant) undertaking should be different when applying EU law and national law. Under EU law, it is the competition authority who should prove a market dominance from the very beginning. Under national law, though, if there is a proceeding against an undertaking holding more than $40 \%$ of the market, the presumption works and it is the company's burden to prove that it is not dominant on a relevant market. So far, this problem has not arisen in Polish case law based on Article 102 TFEU since all decisions related to abuse of dominance addressed companies which were more than dominant (even quasi-monopolistic) - as the President of UOKiK claimed in the PGNiG II decision: $: 25$ a company whose market share is about $95 \%$ holds such a significant position on a market in relation to its contractors and competitors that "it is simply impossible to say that it is not dominant on a market". The same could apply to cases Wrigley (85-90\%) or ZAIKS (100\%).

\footnotetext{
${ }^{23}$ Resolution of the Supreme Court of 23 July 2008, III CZP 52/08.

${ }^{24}$ Article 4.10 of the Polish Competition Act: "dominant position shall mean an undertaking's market position which allows it to prevent effective competition in a relevant market thus enabling it to act to a significant degree independently of its competitors, contracting parties and consumers; it is assumed that an undertaking holds a dominant position if its market share in the relevant market exceeds $40 \%$ ".

${ }^{25}$ Decision of the President of UOKiK, of 13 April 2012, DOK-1/2012 (available in Polish on UOKiK's website).
} 
Differences similar to these concerning an abuse of dominance are also linked with the application of the de minimis rule. Under EU law, this is a rule established in a soft law ${ }^{26}$ and even if it seems fundamental and well-founded in EU competition law, it has some limitations concerning its binding force, as a judgment in the Expedia ${ }^{27}$ case showed..$^{28}$ In Polish competition law, the de minimis rule is expressed in Article 7 of the Competition Act; therefore, it has the status of a hard law with an "absolute" binding force, as the Polish Competition Act does not predict any possibility of abandoning this rule in any circumstances. The substance of the de minimis rules in EU and Polish law is also slightly different: Article 7 of the Polish Competition Act establishes lower market shares for agreements of minor importance than the ones stated in the Commission's communication (5\% for horizontal agreements and $10 \%$ for vertical agreements in Poland against $10 \%$ and $15 \%$ in EU law, respectively).

The same applies to block exemptions. Polish block exemptions are generally patterned on EU group exemptions, but - unlike EU regulations ${ }^{29}$ - they do not contain any provision allowing the President of UOKiK to withdraw block exemption benefits in case of an agreement, theoretically meeting all exempting conditions stated in the Regulation. This brings us to the conclusion that applying a group exemption rule on the basis of a national law may lead to finishing an antitrust proceeding without adopting any decisions confirming an infringement, even in a situation where the Commission - due to extraordinary circumstances - would not apply a block exemption.

The legal (and economic!) sense of de minimis rules and block exemptions is the same in EU and Polish law, but differences in the methodology of their application, as well as in their dimension, are so fundamental that they exclude the possibility of a uniform application when applying Article 101 TFEU and Article 6 of the Polish Competition Act.

\footnotetext{
${ }^{26}$ Commission Notice on agreements of minor importance which do not appreciably restrict competition under Article 101(1) of the Treaty on the Functioning of the European Union (De Minimis Notice), [2014] OJ C 57/1.

${ }^{27}$ Judgment of the Court (Second Chamber) of 13 December 2012, C-226/11 Expedia Inc. v. Autorité de la concurrence and others, EU:C:2012:795.

${ }^{28}$ The Polish Supreme Court also denied a binding force of EU soft law for national authorities (judgment of 7 July 2011, III SK 16/09).

${ }^{29}$ See Article 7 of Regulation (EEC) No. 2821/71 of the Council of 20 December 1971 on the application of Article 85 (3) of the Treaty to categories of agreements, decisions and concerted practices, [1971] OJ L 285/46.
} 


\subsection{2. (Non-) EU competition policy priorities of in a national practice}

Since nowadays competition authorities are not able (due to limited human, organizational, and financial resources) to react to all distortions of competition occurring in a real economy, they set priorities concerning their (competition) policy. In Poland, there is a governmental programme which prescribes competition protection goals for a certain period. In the EU, though, these priorities are formulated merely in a political statement of the Competition Commissioner ${ }^{30}$ and in the Commission's communications - the best example is the Communication from the Commission on its enforcement priorities regarding the application of Article 82 of the EC Treaty to abusive exclusionary conducts by dominant undertakings. ${ }^{31}$

Competition policy priorities at EU and national level do not have to be the same - thus, an important question arises: are national competition authorities obliged to take into consideration EU competition policy priorities indicated by the Commission? The answer to this question should be "yes" if Regulation 1/2003 is to fulfil its basic role - to guarantee a decentralised but uniform application of Articles 101 and 102 TFEU. But if EU competition policy priorities are considered by national authorities as key instructions for applying EU antitrust rules, this can easily lead to a situation where applying identical substantive rules results in different decisions concerning the existence (or non-existence) of a anticompetitive practice. Let me take the above mentioned Commission's communication on Article 102 TFEU as an example. To make a long story short, the idea of this communication is a concentration on the fight against exclusionary abuses instead of investing time and money in dealing with exploitative practices. Just like Article 102 TFEU, Article 9 of the Polish Competition Act, stating a prohibition of any abuse of dominance, does not directly identify two categories of practices (exclusionary and exploitative). But the catalogue of exemplary abuses of a dominant position contained in Article 9(2) of the Polish Competition Act is much longer when compared to the list of abuses in Article 102 TFEU. The enforcement of Article 9 of the Competition Act by the President of UOKiK usually starts with (and quite often it is limited to) a qualification of an undertaking's behaviour as one of the practices listed in a catalogue of abuses under Article 9(2). If it is impossible because a particular behaviour does not meet all the elements of a certain type of

\footnotetext{
${ }^{30}$ E.g. speech by Joaquin Almunia, Fighting against cartels: A priority for the present and for the future, SPEECH/14/281, 3 April 2014. http://europa.eu/rapid/press-release_SPEECH-14-281_en.htm.

${ }^{31}$ [2009] OJ C 45/7.
} 
practice, then the President of UOKiK applies the "general clause" - a "general" prohibition of abuse of a dominant position contained in Article 9(1). It is not an objective of this article to judge whether such a methodology is correct or to decide on a relationship between a general clause stating the prohibition of an abuse and a catalogue of exemplary abuses. However, this is a methodology followed in the majority of cases by the antitrust practice (either by the President of UOKiK or by Polish competition courts). As a result, if all elements of a particular type of abuse - whether exclusionary or exploitative - are present in a certain behaviour, the President of UOKiK confirms an infringement of Article 9 of the Polish Competition Act and - consequently - Article 102 TFEU. It is improbable that a national competition authority will quit a case that can be qualified as an abuse of dominance in the light of a national law (and in fact in the light of the direct wording of Article 102 TFEU) only because it is an exploitative, not exclusionary practice, which in the context of the Commission's Guidelines on Article 102 could even be considered as totally legal.

Even the Commission admits that priorities of cases based on Articles 101 and 102 TFEU differ in NCAs' practice. According to data presented in the Anniversary Communication (paragraph 14), decisions on abuses of a dominant position constitute only 1/5 (20\%) of all the Commission's antirust decisions and almost 1/3 (32\%) of NCAs' decisions concerning the application of EU competition law. Decisions on vertical restraints account for merely $1 / 10$ (9\%) of the Commission's decisional practice, whereas they account for almost 1/5 (18\%) of NCAs' decisions based on the Treaty's provisions. As stated above (section 2), in Poland decisions on vertical restraints predominated for many years.

The statistics presented above require an answer to the question whether a lack of compliance of priorities with the application of EU antitrust rules on a central and "decentralised" level results in a loss of coherence of EU competition policy. Data presented by the Commission also call for a research on how NCAs implement an effects-based approach when applying EU competition law.

\subsection{3. (Different) axiologies of national and EU competition rules}

Another factor that in my view does not a allow a total coherence in the application of EU and national competition rules (which in fact allows for contesting the adequacy of the whole concept of an enforcement regime under Regulation 1/2003) is the axiology of both systems for protecting competition. 
Even if it is taken for granted that nowadays the "pure" protection of competition is a much more important goal of EU law than supporting the integration (and creation) of the single internal market, EU law cannot be - by its nature - totally free from achieving this "integration" goal. It directly results from Protocol No. 26 to the Treaty of Lisbon, where competition rules are mentioned as an imminent part of regulations supporting the functioning of the internal market. No "integration goal" (defined as above) seems to be visible in decisions of national competition authorities, especially if it is not identified with a condition of appreciable impact on intra-EU trade. Regarding the necessity to include an "integration" goal in the application of Articles 101 and 102 TFEU at a national level, the question arises whether it is possible at all to apply EU and domestic competition law in a truly and totally uniform manner.

In this context I would like to highlight the following problem: Article 10 of Regulation 1/2003 mentions the compliance of a Commission's decision with EU public interest as a condition for adopting a decision on non-application of Articles 101 or 102 TFEU, either because a practice does not meet the conditions for prohibitions of anticompetitive practices or because an agreement meets the exemption criteria set in Article 101(3) TFEU or in the de minimis Notice ("Where the Community public interest relating to the application of Articles 81 and 82 of the Treaty so requires (...)"). If a national competition authority takes an analogical decision on a non-application of Articles 101 and 102 TFEU, Article 5 of Regulation 1/2003, which requires in such a situation a decision on "no ground to action on its part", does not demand from NCAs any reference to EU's interest. It is impressive that national competition authorities are not obliged to consider EU's interest in their decisional practice in the same factual and legal situations in which the Commission must, although it is quite clear that in a substantive sense NCAs' decision on no ground to act on their part is the same as a decision on the non-application of Articles 101 and 102 TFEU and only because of formal issues - in order not to eliminate the possibility to conduct a proceeding by other institutions, mainly the Commission - NCAs are not able to adopt decisions on non-application of Treaty provisions (this issue was definitely ruled by the Court of Justice in "Polish" case C-375/09 Tele $2^{32}$.

\footnotetext{
${ }^{32}$ See a positive comment on this judgment by Ilona Szwedziak, "Is the parallel competence set out in Regulation 1/2003 totally clear? Case comment to the preliminary ruling of the Court of Justice of 3 May 2011 Tele 2 v. Prezes Urzędu Ochrony Konkurencji i Konsumentów (Case C-375/09)", Yearbook of Antitrust and Regulatory Studies 5, no. 7 (2011): 263-273.
} 


\section{3. (Partly) simultaneous application of EU and national competition rules}

Article 3 of Regulation 1/2003 predicts that the enforcement of Articles 101 and 102 TFEU is possible only within a proceeding where EU law is applied altogether with a national law. Let us imagine that a national authority is convinced about a distortion of competition by an agreement that - in the light of a national law - is caught by a block exemption, but does not need to be subject to EU block exemption because of a withdrawal of benefits by the Commission (this problem was summarised in section 3.2.1 above). Is a national competition body entitled to continue a proceeding only on the basis of Article 101 TFEU? Such a problem remains actually unsolved by Regulation 1/2003. Article 3 of Regulation 1/2003 refers to the simultaneous application of EU and national law. What the Council probably meant by "application" is making a decision (by a competition authority) on the substance of a case - this may be a decision declaring a violation of Article 101 or Article 102 TFEU or an exempting decision based on Article 101(3) TFEU. In my view, e.g. a decision to abandon a proceeding as a result of applying a national block exemption is in fact a decision on the substance of a case; therefore, it is a decision on the application of a national competition law. Unfortunately, due to some discrepancies in EU and national laws, the result of applying national and EU rules is totally different. If such a factor were to be considered as a reason to quit a proceeding concerning Article 101 TFEU by a national authority, the idea of decentralisation would be distorted. Nevertheless, it is doubtful that any competition authority would take the risk of continuing a proceeding solely in relation to Article 101 TFEU - the direct wording of Article 3 of Regulation $1 / 2003$ rather suggests that in the situation described above there is no ground for a national competition authority to continue a proceeding (in fact, the condition of simultaneous application of EU and national law is not met anymore), and such a proceeding should be taken over by the Commission. Even if such situations are marginal, EU regulation should somehow respond to the problem.

\subsection{Sanctions for violating Articles 101 and 102 TFEU: differentiation, multiplication}

There are two basic problems with sanctions for violating Articles 101 and 102 TFEU in a decentralised system of EU competition law enforcement. The first one is the application of different sanctions for the same violation of common competition rules. One of the conditions for a totally 
uniform application of EU and national competition rules is a uniformity of sanctions imposed on undertakings, regardless of whether Article 101 or Article 102 were applied by the Commission or NCA. Yet, sanctions for antitrust practices are not unified or harmonised at all. In the Anniversary Communication (paragraph 36), the Commission claims that regarding administrative sanctions Member States achieved a high level of voluntary convergence because competition authorities operate a similar methodology, but simultaneously it admits that there are still some differences concerning principles for calculating fines, such as: basis for calculating the fine, basic amount of the fine, method of including in a fine a gravity and a period of infringement. For undertakings - potential addressees of decisions imposing fines - these differences have a fundamental meaning. ${ }^{33}$

For instance, unlike Article 23(2) of Regulation 1/2003, which takes a turnover as a reference point for calculating a fine, Article 106(1) of the Polish Competition Act used to establish undertakings' incomes as a base for calculating a fine. Under these circumstances, even if a methodology for calculating fines laid down in soft law is coherent (or even unified), its application leads to different results (fines of various amounts for a violation of Articles 101 and 102 TFEU, depending if they are imposed by the Commission or NCA in a particular Member State). Fortunately, in the Polish practice this problem was solved in the amendment of the Competition Act dated 10 June 2014 and, on 18 January 2015 (when the amendment entered into force), income was replaced by turnover as a base for calculating fines.

But even if the discrepancy between EU and national competition law mentioned above was eliminated, the other fundamental difference, concerning the leniency programme, still exists, even if this particular solution of Polish competition law has been widely criticised in the Polish doctrine. ${ }^{34}$ Poland belongs to a very narrow circle of countries where leniency applies not only to cartels, but also to vertical agreements. Indeed, a majority of cases in which undertakings were granted immunity or reduction of a fine were about violations of a prohibition of anticompetitive agreements

\footnotetext{
${ }^{33}$ Divergences on administrative fines were correctly listed in paragraphs 70-76 of the Commission Staff Working Document enhancing competition enforcement by the Member States' competition authorities: institutional and procedural issues: accompanying Communication from the Commission to the European Parliament and the Council - Ten Years of Antitrust Enforcement under Regulation 1/2003: Achievements and Future Perspectives \{COM(2014) 453\} \{SWD(2014) 230\}. ${ }^{34}$ Bartosz Turno, Leniency. Program łagodzenia kar pieniężnych $w$ polskim prawie ochrony konkurencji, (Warsaw: Wolters Kluwer, 2013): 460-465 (published only in Polish).
} 
by vertical restraints. So, in many cases, an undertaking lenient in Poland would not be lenient in other Member States - it only confirms the fact that unless a leniency applicant makes multiple (and successful) applications across the EU, "there would be no real certainty of EU-wide immunity" 35.

The fact that such broad categories of undertakings (including those engaged in vertical agreements) are allowed to benefit from leniency programmes may be considered as beneficial for companies, but it can also be treated - and a record of the decisions of the President of UOKiK confirms that - as a solution that actually makes leniency less effective over time. As a consequence, the effectiveness of the competition policy as such is diminished, which is surely against undertakings' interests.

The Polish system of sanctions for anticompetitive practices also raises another problem - the interaction between sanctions imposed on undertakings and on individuals. They may be - but of course - sanctions for violating Article $101 \mathrm{TFEU}^{36}$ - so, in fact, it is a question of effective sanctioning for infringements of EU law. There are many problems to be solved in this area, among them the relation between sanctions suffered by a company and by a natural person in a situation where a company benefits from a leniency. In the past, such a problem did not exist in Poland, as the Competition Act did not prescribe any sanctions on individuals, but Article 106a, in relation to Article 6a (which entered into force on 18 January 2015), provides the possibility to impose a fine up to $2,000,000$ PLN (ca. 500,000 EUR) on individuals ("managing person", as defined in Article 4.3a of the Competition Act). The Commission also notices the necessity of working out a proper (we prefer: well-balanced) relation between sanctions imposed on both categories of entities. ${ }^{37}$

Apart from a possible differentiation of sanctions for the same infringement at EU and national level, a decentralised enforcement of Articles 101 and 102 TFEU brings a problem of multiplication of sanctions: concurrent (and different) sanctions which can be imposed by various NCAs conducting their national proceedings in the case of the same infringement. It can be assumed that solving this problem would be limited by the application

\footnotetext{
${ }^{35}$ Ionnis Lianos and Arianna Andreangeli, “The European Union: The competition law system and the Union's norms", in Design of Competition Law Institutions: Global Norms, Local Choices, eds. Eleanor M. Fox, Michael J. Trebilcock (Oxford: Oxford University Press, 2013): 432.

${ }^{36}$ A fine on a natural person may be imposed solely for an infringement of a prohibition of anticompetitive agreements, not a prohibition of an abuse of a dominant position.

${ }^{37}$ Anniversary Communication, paragraph 42.
} 
ne bis in idem rule, but such a general statement seems a bit dissatisfying. A decision upon this issue in more detail at EU level has been highly expected by undertakings.

In the Anniversary Communication, the Commission underlined the need to initiate some actions for enhancing a convergence of sanctions combined with a certain level of flexibility for NCAs in the calculation of fines in individual cases..$^{38}$ It seems a good start for amending the existing regime.

\subsection{Cooperation between the Commission and national institutions: far from the picture settled in Regulation 1/2003}

\subsubsection{Poor cooperation of both the Commission and the national courts}

Guaranteeing a uniform application of EU competition law in Member States is not exclusively the Commission's task, it can be also attributed to national competition authorities (regardless of whether they are administrative or judicial). An obligation to contribute to a uniform application of the Treaty's provisions can be easily drawn from the loyalty principle laid down in Article 4(3) TEU. Regulation 1/2003 provides some instruments that can be used by national authorities to fulfil this obligation. Article 15(1) of Regulation 1/2003 gives national courts the possibility to "ask the Commission to transmit to them information in its possession or its opinion on questions concerning the application of the Community competition rules". Between 2004 and 2017, the Commission was asked for information/an opinion only in 34 cases. ${ }^{39}$ A significant number of requests was just seeking a piece of information on how advanced a proceeding conducted by the Commission was. The number of requests from national courts is quite low - an average of 1.2 applications per State. The method of cooperation provided by Article 15(1) of Regulation 1/2003 seems to be rather ineffective. Why? Maybe national courts prefer to solve their problems through the application of Articles 101 and 102 TFEU by making a reference for a preliminary ruling to the European Court of Justice rather than by cooperating with the administrative and political body the Commission actually is. Anyway, the reasons for the unsatisfying application of Article 15(1) should have been thoroughly examined by the

\footnotetext{
${ }^{38}$ Anniversary Communication, paragraph 38.

${ }^{39}$ Data available at: http://ec.europa.eu/competition/court/antitrust_requests.html (January 15, 2018).
} 
Commission with regard to improving a decentralised system of enforcing EU competition rules.

The Commission can also stand up as amicus curiae, presenting its position in certain cases before national courts (Article 15(3) Regulation 1/2003). Until the end of 2015, the Commission submitted its observations in 17 cases to courts in 9 Member States (none of them was Poland). ${ }^{40}$ This number is also very low and it probably does not reflect the real number of cases respecting the application of Articles 101 and 102 TFEU before national courts. Naturally, we do not require the Commission to get its interest in every single case before a national court, but regarding the fact that due to CJEU's jurisprudence the Commission can act as amicus curiae either within public or private enforcement of competition law, there must have been much more problematic cases than just 17! If the Commission itself - which is absolutely the very first to guarantee a uniform application of EU law throughout Member States - is not eager to co-operate with courts, it is no wonder courts do not feel much encouraged to contact the Commission.

\subsection{2. (Non-) notification of judgments by national courts}

It was mentioned above that national institutions are obliged by a loyalty principle to contribute to a uniform application of EU competition law. Article 15(2) of Regulation 1/2003 makes this obligation even more concrete: it requires Member States to forward to the Commission "any written judgment of national courts deciding on the application of Article 81 or Article 82 of the Treaty". Surely a common knowledge of national jurisprudence on the application of Articles 101 and 102 TFEU is absolutely desired by all parties interested in enforcing EU competition rules (including Regulation 1/2003) - undertakings, their lawyers, and competition authorities themselves. Accessibility to judgments of national courts should be considered as a method to monitor the enforcement of Articles 101 and 102 TFEU at a national level. Unfortunately, this method did not work. The record of judgments available at the Commission's website is beyond poor - for instance, there is no judgment of the Polish court! Member States totally ignored the duty to deliver judgments and the Commission did not use any of its instruments to force Member States to do it. One should note

\footnotetext{
${ }^{40}$ Data available at: http://ec.europa.eu/competition/court/antitrust_amicus_curiae.html (January $15,2018)$.
} 
that the duty to submit a judgments is a duty imposed by Member States by a (binding) regulation, not (non-binding) soft law, which means that ignoring this duty is a direct violation of EU law.

It would be recommendable to make the provision in Article 15(2) even more precise by stating that national courts should also forward to the Commission judgments that are not ultimate (this can be read indirectly in the current version of the provision: "any written judgments"). The idea of translating judgments into English should also be considered, as publishing verdicts in English could highly enhance the usefulness of the Commission's record.

\subsection{Final remarks: deficiencies of the current system of application of $E U$ competition rules (not only) from the Polish standpoint}

The analysis of the record of Polish antitrust decisions and jurisprudence allows for the conclusion that the enforcement of Articles 101 and 102 TFEU has not been very intense, not to say poor. The Polish experience with EU competition rules does not have to be representative for all the Member States; still, it describes EU competition law's related practice in the sixth largest country (and consumer market) in the EU. Surely, there may be many reasons for such a low record of Article 101 and Article 102 TFEU cases on the Polish playground, but at least some of them result from difficulties in enforcing Regulation 1/2003. The fact that Poland belongs to the "new" Member States cannot be regarded as a real source of low intensity in the enforcement of Articles 101 and 102 TFEU, as antitrust law developed in Poland since 1990 and was patterned on EU law from the very beginning, which means that the Polish competition authority has enough experience to apply Treaty antitrust rules successfully. Many of the "old" (incumbent) Member States issued their competition acts during that same period or just a few years later.

The effectiveness of Regulation 1/2003 does not depend on whether it is enforced by a "new" or an "old" Member State. To the contrary, it should be concluded that deficiencies of the Regulation appear in the new States that joined in 2004 as well as in the old ones. If the "intensity" of the application is to be measured with the number of preliminary rulings delivered in last 10 years, the assessment is rather balanced (Tele 2 and Toshiba ${ }^{41}$ from

\footnotetext{
${ }^{41}$ Judgment of the Court of Justice of 14 February 2012, C17/10 Toshiba Corporation and others $v$. Úřad pro ochranu hospodářské soutěže, EU:C:2012:72.
} 
the "new" Member States versus Vebic ${ }^{42}$ and Schenker from the "old" ones). Therefore, many remarks regarding the functioning of Regulation 1/2003 presented in the article based in the Polish experience respecting the practice of application of the Regulation may also be true for other Member States (in terms of procedural peculiarities).

Regulation 1/2003 cannot be considered as an effective tool for decentralising the enforcement of Articles 101 and 102 TFEU, assuming that common competition rules should be applied in a uniform and consistent manner all over the EU. Among the reasons for this ineffectiveness are some inconsistencies between substantive EU and national rules, slightly different axiologies and goals of $\mathrm{EU}$ and national competition laws, and different sanctions for violating prohibitions of anticompetitive rules. Practical problems, such as the risk of multiplication of sanctions for the same violation in different Member States, should also be considered as a deficiency in the decentralised system of enforcing Treaty competition rules.

\section{ECN+ Directive Proposal: does it respond to the deficiencies of Regulation 1/2003?}

\subsection{Introductory remarks}

After the Commission's evaluation of the application of Regulation 1/2003 in 2014, it became clear that the decentralised enforcement of EU competition rules had to be strengthened. The first step was an entire review of Regulation 1/2003, the second was to offer Member States a new approach based on the alignment of the basic procedural principles to be followed by NCAs and courts when enforcing Articles 101 and 102 TFEU. As it was evident that "corrections" or "amendments" of the existing law were not sufficient, the Commission decided to go for a harmonisation of the procedure in cases where European substantive law was to be applied..$^{43}$ The argument that harmonising antitrust procedures in EU Member States is

\footnotetext{
${ }^{42}$ Judgment of the Court of Justice of 7 December 2010, C-439/08 Vebic, EU:C:2010:739.

${ }^{43}$ See also a statement of Andreas Mundt, President of the Bundeskartellamt: "Spreading the harmonisation of substantive law effected by Regulation 1/2003 to institutional and procedural aspects will serve to further strengthen the ECN authorities, and thus ensure that the EU's unique form of decentralised antitrust enforcement will continue to thrive" - Adreas Mundt, "The ECN's way ahead: Making decentralised antitrust enforcement waterproof", Journal of European Competition Law \& Practice 5, no. 8 (2014): 520.
} 
blocked by a principle of procedural autonomy ${ }^{44}$ turned out to be weaker in the second decade of the $21^{\text {st }}$ century than before. ${ }^{45}$ Indeed, harmonising procedural rules of public enforcement of EU competition law seems much less risky than - successfully completed in the form of an Antitrust Damage Directive ${ }^{46}$ - the harmonisation of the private enforcement of EU antitrust rules.

The proposal for the ECN+ Directive contains a list of gaps that - in the Commission's view - need to be solved by the EU legislation. This list covers: (1) a lack of independence from public authority in applying EU law; (2) a lack of tools to detect and deal effectively with competition law infringements; (3) an inability to impose effective fines; (4) differences in leniency programmes; (5) insufficient tools for mutual assistance among $\mathrm{NCAs}^{47}$.

\subsection{Are there any ECN+ Directive Proposal's responses to deficiencies from the Polish perspective?}

\subsubsection{Gaps stemming from the interpretation of substantive rules}

The weaknesses of the decentralised enforcement of EU competition law summarised in section 3 above cover three areas of problems. The first one concerns various aspects of interpretation of substantive rules: the reluctance of a competition authority to solve simple gaps in the interpretation of substantive rules at EU and national level, the lack of a full identity of the methodology for applying EU and domestic substantive rules (e.g.

\footnotetext{
${ }^{44}$ More on a procedural autonomy of Member States in antitrust (with a nexus to Poland) - see Krystyna Kowalik-Bańczyk, "Procedural autonomy of Member States and the EU rights of defence in antitrust proceedings", Yearbook of Antirust and Regulatory Studies 5, no. 6 (2012): 215-234.

${ }^{45}$ Sceptically about a possibility of harmonising procedural rules in antitrust - Kati Cseres, "Comparing laws in the enforcement of EU and national competition laws", European Journal of Legal Studies 3, no. 1 (2010): 7-44. This author, nevertheless, claims that the analysis of the decentralised enforcement system in Central and Eastern Europe (CEE) points "to the need for more (re)-centralization, or at least for more central steering" for applying EU competition rules - see Kati Cseres, "The European Competition Network as experimentalist governance: The case of the CEECs", Draft paper to be presented at the ECPR Standing Group on Regulatory Governance Conference, Barcelona, 25-27 June 2014, 20 (available at http://reggov2014.ibei.org/bcn-14-papers/34-35.pdf).

${ }^{46}$ Directive 2014/104/EU of the European Parliament and of the Council of 26 November 2014 on certain rules governing actions for damages under national law for infringements of the competition law provisions of the Member States and of the European Union, [2014] OJ L 349/1.

${ }^{47}$ See the Proposal for ECN+ Directive, 2-3 (under the heading: Reasons for and objectives of the proposal).
} 
presumption of dominance in Polish law), the lack of a fully common axiology at supranational and national level.

Regarding the problem of a gap in the priorities of both the EU and national competition policies, Article 4(2)(e) of the draft Directive does not solve it, it rather strengthens it. National competition authorities are given total independence in setting "their priorities for carrying out tasks for the application of Articles 101 and 102 TFEU as defined in Article 5(2)". The planned regulation provides national competition authorities with a power "to reject such complaints on the grounds that they do not consider them to be a priority". Instead of approaching national priorities to EU priorities in the application of substantive competition rules, the draft Directive proposes a competition policy consisting of 28 (or rather 27) national EU-related policies - this is how Article 4(2)(e) can be understood. I profoundly doubt whether it really enhances uniformity in the application of Articles 101 and 102 TFEU.

\subsubsection{Gaps related to procedures and sanctions}

The second area of deficiencies of the current enforcement system concerns a procedural uncertainty in cases where a simultaneous application of the Treaty rules and national rules is not evident because of gaps in procedural provisions (e.g. a gap resulting from the lack of a possibility to withdraw from a block exemption under Polish law). The second area concerns differences in sanctions.

Regulations of procedural issues are contained in Chapter IV of the ECN+ Directive proposal (Article 6 - 12). It starts with a regulation on the powers to inspect business and non-business premises. Even the most revolutionary provisions herein - Article 6 and Article 7 of the draft Directive - bring no innovative solution to the Polish legislation. Due to Article 105a-105q PCA, the UOKiK enjoys a power to inspect which generally complies with the model proposed in Article 6 of the ECN+ Directive. A power to request information, prescribed in Article 8 of the draft Directive, is also one of the powers commonly used by the Polish $\mathrm{UOKiK}$ - its efficiency is safeguarded by relatively severe (and practically imposed) fines.

The draft Directive provides (through Article 9) a national competition law with the possibility to impose behavioural or structural remedies which could support an order to terminate an infringement. It is rather surprising, given the fact that the Commission itself imposed 
remedies due to Article 7 of Regulation 1/2003 in a few antitrust cases. ${ }^{48}$ Nevertheless, the Polish legislator anticipated the Commission's intent and from 18 January 2015 on, both behavioural and structural remedies can be imposed on parties of antitrust proceedings before the UOKiK on the basis of Article 10(4) of the Polish Competition Act (so far, the Polish NCA has not used its power in this regard). Other measures concerning undertakings' obligations within antitrust proceedings proposed by the ECN+ Directive - these are interim measures (Article 10) and commitments (Article 11) - are secured in the Polish system by Articles 87 and 12 of the Polish Competition Act, respectively.

Regulations on antitrust fines and periodic penalty payments are contained in Chapter V of the ECN+ Directive Proposal. Article 106 of the Polish Competition Act shows a conformity with Article 12 of the draft Directive, which points activities subject to fines, although the Polish lawmaker is not so detailed as the Commission and does not mention breaking the seals fixed during an inspection as a separate basis for fining (Article 12(2)(b) ECN+ Directive Proposal).

What the Polish Competition Act lacks is a direct counterpart of Article 12(3) of the ECN+ Directive Proposal, which states that: "Member States shall ensure that the notion of undertaking is applied for the purpose of imposing fines on parent companies and legal and economic successors of undertakings". In my opinion, such a provision in a national competition law will not only ease imposing fines on entities indirectly liable for an infringement, but it will also somehow confirm the presence of the concept of a single economic unit in Polish antitrust practice and jurisprudence. A provision concerning a calculation of fines in case of infringements by associations of undertakings (Article 13(2) ECN+ Directive Proposal) will also be a brand new regulation in Polish antitrust law. Principles for calculating fines and imposing periodic penalty payments in current Polish legislation are not different from the ones proposed in Articles 13(1) and 14 of the draft Directive.

What is extraordinarily valuable in the ECN+ Directive Proposal is the introduction of unified rules for leniency application (Chapter VI, Article 16-21). In fact, the draft Directive turns a great part of the Model Leniency Programme worked out by ECN into a hard law. Surely, these regulations

${ }^{48}$ A review of Commission's practice with behavioural remedies until the end of 2015 is summarised in: Cyril Ritter, "How far can the Commission go when imposing remedies for antitrust infringements", Journal of European Competition Law \& Practice 7, no. 9 (2016): 587-598. 
on leniency do not solve problems of discrepancies between EU and Polish competition law concerning leniency (see III.4. above), but hopefully they will be an inspiration for changing the Polish model of leniency into an institution, being a tool for fighting secret cartels solely (not all anticompetitive agreement). Article 22 of the ECN+ Directive Proposal provides the possibility to establish a proper relation between liability of undertakings and liability of natural persons for infringements of competition rules in terms of antitrust law efficiency. The introduction of such a regulation will be of great benefit for the application of both EU law and a domestic law which launched a liability of natural persons for anticompetitive agreements (Article 6a PCA).

\subsubsection{Gaps related to inter-institutional cooperation}

Cooperation between national competition authorities is addressed in Chapter VII of the ECN+ Directive Proposal. Mutual assistance in a form proposed in the draft Directive goes far beyond current possibilities of cooperation between NCAs. A request for a notification of preliminary objections and decisions (Article 24) and, even more, a request for an enforcement (Article 25) will bring a real involvement of competition authorities from many Member States which will probably make the whole system of public enforcement of EU competition rules more coherent and - as a result - more effective.

Enforcement of these new methods of cooperation is properly safeguarded. Article 26 of the ECN+ Directive Proposal introduces preventive measures in case of any disputes concerning such an advanced cooperation between national competition bodies, and Article 27 establishes the suspension of a limitation period for the imposition of fines in case of concurrent antirust proceedings before authorities in different Member States. Another "safety device" for an advanced cooperation is established in Article 29, which introduces rules on limitation of use of information provided in NCAs' communications and common activities. Additionally, the ECN+ Directive Proposal insists on the existence of a national judicial competition authority to respond to claims by national administrative competition authorities (Article 28). It seems that this instruction is fully followed by a current institutional system for protecting competition in Poland. Finally, the ECN+ Directive Proposal points a list of types of evidence admissible before national competition authorities, and Article 51-59 PCA in principle complies with it. 


\section{Closing remarks}

The future ECN+ Directive wants to introduce "necessary guarantees of independence and resources and enforcement and fining powers [for NCAs] to be able to effectively apply Articles 101 and 102 TFEU" (Article 1). Even if what W.P.J. Wils claims is true ("At least for some of the provisions of the proposed Directive, it could be argued that they do not create any new obligations for the Member States, as the same obligation already flows from Article 35 of Regulation 1/2003"49), the wide scope of the planned ECN+ Directive is more than ambitious. However, in my personal view, the new regulation will not solve the majority of problems regarding the application of Articles 101 and 102 TFEU by NCAs, it rather seems to be only a small step ahead.

Trying to answer a key question behind this article - will the ECN+ Directive eliminate the deficiencies of Regulation 1/2003? - I regretfully say: no. As pointed above, the draft Directive hardly touches problems with a concurrent application of EU and national competition law by a national competition body. Surely, this is a subjective view stemming from the Polish perspective, but taking as a starting point the analysis in section 3 of this article, the real impact on the improvement of a concurrent application of EU and national antitrust law can be bound only with Articles 12(3), 22, 23-27 and 29 of the ECN+ Directive Proposal. Other regulations will contribute to a better enforcement of competition law, but they have almost no significance in a tension resulting from enforcing Regulation 1/2003 by a concurrent application of EU competition law and a national competition law.

The ECN+ Directive, if adopted in the proposed version, will certainly improve the enforcement of competition rules in Member States, regardless of whether EU law is applied. Maybe the implementation of the ECN+ Directive will follow the same path as the implementation of the Antitrust Damage Directive - legal rules originally prescribed for applying EU competition law were broadened to the application of national rules.

\footnotetext{
${ }^{49}$ Wouter Wils, "The European Commission's "ECN+": Proposal for a Directive to empower the competition authorities of the Member States to be more effective enforcers", Concurrences 4 (2017): 65 .
} 


\section{Bibliography}

Almunia, Joaquin. "Fighting against cartels: A priority for the present and for the future", SPEECH/14/281, 3 April 2014.http://europa.eu/rapid/press-release_SPEECH -14-281_en.htm).

Cseres, Kati. "Comparing laws in the enforcement of EU and national competition laws”. European Journal of Legal Studies 3, no. 1 (2010): 7-44.

Cseres, Kati. "The impact of Regulation 1/2003 in the new Member States". The Competition Law Review 6, no. 2 (2010): 145-182.

Kowalik-Bańczyk, Krystyna. "Procedural autonomy of Member States and the EU rights of defence in antitrust proceedings". Yearbook of Antirust and Regulatory Studies 5, no. 6 (2012): 215-234.

Lianos, Ioannis, and Andreangeli, Arianna. "The European Union: The competition law system and the Union's norms". In Design of Competition Law Institutions: Global Norms, Local Choices, edited by Eleanor M. Fox and Michael J. Trebilcock. Oxford: Oxford University Press, 2013.

Malinauskaite, Jurgita. "Public EU competition law enforcement in small 'newer' Member States: Addressing the challenges". The Competition Law Review 12, no. 1 (2016): 19-52.

Monti, Giorgio. "Independence, interdependence and legitimacy: The EU Commission, National Competition Authorities, and the European Competition Network". EUI Working Paper LAW 1 (2014).

Mundt, Andreas. “The ECN's way ahead: Making decentralised antitrust enforcement waterproof”. Journal of European Competition Law \& Practice 5, no. 8 (2014): 519-520.

Ritter, Cyril. "How far can the Commission go when imposing remedies for antitrust infringements?". Journal of European Competition Law \& Practice 7, no. 9 (2016): 587-598.

Szwedziak, Ilona. "Is the parallel competence set out in Regulation 1/2003 totally clear? Case comment to the preliminary ruling of the Court of Justice of 3 May 2011 Tele 2 v. Prezes Urzędu Ochrony Konkurencji i Konsumentów (Case C-375/09)”. Yearbook of Antitrust and Regulatory Studies 5, no. 7 (2011): 263-273.

Turno, Bartosz. Leniency. Program łagodzenia kar pieniężnych w polskim prawie ochrony konkurencji. Warsaw: Wolters Kluwer, 2013.

Wils, Wouter. “Ten years of Regulation 1/2003 - A retrospective”. Journal of Competition Law and Practice 4, no. 4 (2013): 293-301.

Wils, Wouter. “The European Commission's 'ECN+': Proposal for a Directive to empower the competition authorities of the Member States to be more effective enforcers". Concurrences 4 (2017): 60-80. 